\title{
System Yields, Nutrient Uptake and Balance of Mustard-Mungbean-T. Aman Rice Cropping Systems in Terrace Soils of Bangladesh
}

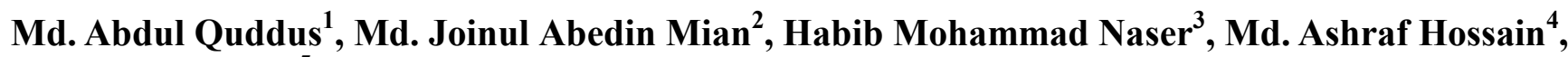 \\ Md. Abdus Sattar ${ }^{5}$ \\ ${ }^{1}$ Soil and Water Management Section, Horticulture Research Centre, Bangladesh Agricultural Research Institute, Gazipur, Bangladesh \\ ${ }^{2}$ Department of Soil Science, Bangladesh Agricultural University, Mymensingh, Bangladesh \\ ${ }^{3}$ Soil Science Division, Bangladesh Agricultural Research Institute, Gazipur, Bangladesh \\ ${ }^{4}$ Pulses Research Sub-Station, Bangladesh Agricultural Research Institute, Gazipur, Bangladesh \\ ${ }^{5}$ Olericuture Division, Horticulture Research Centre, Bangladesh Agricultural Research Institute, Gazipur, Bangladesh
}

\section{Email address:}

Quddus06@yahoo.com (M. A. Quddus), joinul.ss@gmail.com (M. J. A. Mian), nasemh2@yahoo.com (H. M. Naser), ashrafbd61@yahoo.com (M. A. Hossain), sattar72@gmail.com (M. A. Sattar)

\section{To cite this article:}

Md. Abdul Quddus, Md. Joinul Abedin Mian, Habib Mohammad Naser, Md. Ashraf Hossain, Md. Abdus Sattar. System Yields, Nutrient Uptake and Balance of Mustard-Mungbean-T. Aman Rice Cropping Systems in Terrace Soils of Bangladesh. Journal of Energy and Natural Resources. Vol. 6, No. 2, 2017, pp. 14-23. doi: 10.11648/j.jenr.20170602.11

Received: February 20, 2017; Accepted: March 20, 2017; Published: April 10, 2017

\begin{abstract}
Conducted experiments on mustard-mungbean-T. aman rice cropping system to measure the system yield, nutrient uptake and apparent balance in terrace soils of Gazipur. Four fertilizer treatments were considered viz. absolute nutrient control $\left(T_{1}\right)$; farmer's practice $\left(T_{2}\right)$; AEZ basis fertilizer application $\left(T_{3}\right)$ and soil test basis fertlizer application $\left(T_{4}\right)$. The treatments were compared in a randomized completely block design with three replications over two consecutive years. The average yields of mustard, mungbean and T. aman rice ranged from 798 to $1543 \mathrm{~kg} \mathrm{ha}^{-1}, 995$ to $1489 \mathrm{~kg} \mathrm{ha}^{-1}$ and 3270 to $4521 \mathrm{~kg} \mathrm{ha}^{-1}$, respectively showing $T_{4}$ as the best treatment. Soil test basis fertilizer application $\left(T_{4}\right)$ exhibited the highest nutrients uptake by all tested crops. The apparent balance of $\mathrm{N}$ and $\mathrm{K}$ was negative; however it was less negative for $\mathrm{T}_{4}$ treatment. The apparent $\mathrm{P}$ balance was positive in $T_{2}, T_{3}$ and $T_{4}$ but negative in $T_{1}$. Positive $S$ balance observed in $T_{4}$ but negative in $T_{1}, T_{2}$ and $T_{3}$. Zinc and $\mathrm{B}$ balance in the system was positive in case of $\mathrm{T}_{3}$ and $\mathrm{T}_{4}$. Highest yield, gross margin and soil fertility have been recommended that the soil test basis fertilizer application is profitable for mustard-mungbean-T. aman rice cropping system in terrace soils. The study indicate clearly an opportunity for the re-adjustment of the N, P, K, S and miconutrients ( $\mathrm{Zn} \mathrm{\&} \mathrm{B)}$ fertilizer doses for the different rice-based cropping systems in Bangladesh.
\end{abstract}

Keywords: System Yield, Nutrient Uptake, Nutrient Balance, Mustard-Mungbean-T. Aman Rice, Terrace Soil

\section{Introduction}

Terrace soils under the agro-ecological zone-Madhupur Tract which belongs to Dhaka, Gazipur, Tangail, Narshingdi, Narayangonj and Kishorgonj districts of Bangladesh. Rice is the staple crop in Terrace soils of Gazipur, but some farmers are grown mustard and vegetables in Rabi season [1]. Mustard (Brassica napus), mungbean (Vigna radiata) and T. aman rice (Oryza sativa L.) grown sequentially in an annual rotation constitute a mustard-mungbean-T. aman cropping system.
Several studies have shown that intensive rice-based cropping system including rice-wheat (RW) causes remarkable depletion of soil nutrients and threat to crop productivity [2]. Besides the farmers are following imbalanced use of fertilizers for crop production which leads to degrade soil fertility [3]. Farmers generally use fertilizers on single crop basis, not the cropping system. High yielding varieties of crops uptake higher amount of nutrients from soils resulting in depletion of soil organic matter and deterioration of soil fertility, poses a great threat to sustainable crop production. Moreover, continuous cropping 
without adequate replacement of removed nutrients and nutrient loss through erosion, leaching, and gaseous emission have caused depletion soil fertility as well as soil organic matter [4].

The bulk of literature indicates that, apart from residue management, cropping system productivity may become sustainable through integrated use of organic and inorganic sources of nutrients [5]. Hence, it is important to develop a cropping system based fertilizer dose for specific agroecological zone. Quantification of the loss or gain of nutrients under different cropping system has been less attended. Nutrient balance is an important tool for assessing the nutrient reserve in soils. Crop nutrient balance is a difference between nutrients applied to soil in relation to its removal by crops and leaching loss. Negative nutrient balance may limit crop yield and deplete soil fertility and positive nutrient balance shows nutrient accumulation and creates a risk of water and air pollution [6]. It is hypothised that the current fertilizer recommendation could be improved for a definite cropping system. Thus, the aim of this study was to compare system yields, nutrient uptake and nutrient balance for the mustard-mungbean- $\mathrm{T}$. aman rice cropping system with varying fertilizer management practices.

\section{Materials and Methods}

\subsection{Site Description}

The two years (2009-10 and 2010-11) experiment on mustard-mungbean-T. aman cropping systems were conducted at the research field of Bangladesh Agricultural Research Institute, Joydebpur, Gazipur (24 ${ }^{\circ} 0^{\prime} 13^{\prime \prime} \mathrm{N}$ latitude and $90^{\circ} 25^{\prime} 0^{\prime \prime}$ E longitude) lies at an elevation of $8.4 \mathrm{~m}$ above the sea level. The terrace soils of Gazipur is medium high land with fine-textured (clay loam) belongs to Chhiata series (Soil taxonomy: Udic Rhodustalf) under the agro ecological zone - Madhupur Tract (AEZ-28).

\subsection{Experiment Set-Up}

The experiments were carried out over the three crop seasons such as Rabi (mid October to mid March), Kharif-I (mid March to mid June) and Kharif-II (mid June to mid October).

\subsubsection{Treatment and Layout}

The experiment consisted of four treatments-absolute nutrient controls $\left(\mathrm{T}_{1}\right)$; farmer's practice $\left(\mathrm{T}_{2}\right)$; AEZ basis fertilizer application $\left(T_{3}\right)$ and soil test basis fertlizer application $\left(\mathrm{T}_{4}\right)$. Descriptions of the different treatments are given in Table 1.

Table 1. Rates of fertilizers $\left(\mathrm{kg} \mathrm{ha}^{-1}\right)$ for mustard, mungbean and T. aman.

\begin{tabular}{llll}
\hline Treatments & Mustard & Mungbean & T. aman \\
\hline $\mathrm{T}_{1}$ & Control & Control & Control \\
$\mathrm{T}_{2}$ & $\mathrm{~N}_{100} \mathrm{P}_{15} \mathrm{~K}_{20}$ & $\mathrm{~N}_{6} \mathrm{P}_{5} \mathrm{~K}_{4}$ & $\mathrm{~N}_{60} \mathrm{P}_{6} \mathrm{~K}_{20}$ \\
$\mathrm{~T}_{3}$ & $\mathrm{~N}_{85} \mathrm{P}_{20} \mathrm{~K}_{55} \mathrm{~S}_{15} \mathrm{Zn}_{0} \mathrm{~B}_{1}$ & $\mathrm{~N}_{7} \mathrm{P}_{7} \mathrm{~K}_{5}$ & $\mathrm{~N}_{65} \mathrm{P}_{7} \mathrm{~K}_{28} \mathrm{~S}_{8} \mathrm{Zn}_{1}$ \\
$\mathrm{~T}_{4}$ & $\mathrm{~N}_{105} \mathrm{P}_{24} \mathrm{~K}_{60} \mathrm{~S}_{20} \mathrm{Zn}_{2} \mathrm{~B}_{2}$ & $\mathrm{~N}_{15} \mathrm{P}_{20} \mathrm{~K}_{10} \mathrm{~S}_{6} \mathrm{Zn}_{1} \mathrm{~B}_{1}$ & $\mathrm{~N}_{70} \mathrm{P}_{12} \mathrm{~K}_{40} \mathrm{~S}_{10} \mathrm{Zn}_{1} \mathrm{~B}_{1}$ \\
\hline
\end{tabular}

The experiment was laid out in randomized complete block design with three replications. The unit plot size was 4 $\mathrm{m} \times 3 \mathrm{~m}$ for all crops having the spacing of $30 \mathrm{~cm} \times 10 \mathrm{~cm}$ for mustard, $30 \mathrm{~cm} \times 10 \mathrm{~cm}$ for mungbean and $20 \mathrm{~cm} \times 15$ $\mathrm{cm}$ for $\mathrm{T}$. aman rice.

\subsubsection{Fertlizer Application and Seed Sowing}

Full amount of fertilizers, except urea in mustard and rice was applied to respective plot during final land preparation. Urea was applied in two equal split for mustard and three equal splits for T. aman rice. The sources of $\mathrm{N}, \mathrm{P}, \mathrm{K}, \mathrm{S}, \mathrm{Zn}$ and B were urea, triple super phosphate, muriate of potash, gypsum, zinc sulphate and boric acid, respectively. The first crop mustard (var. BARI Mustard-14) were sown on mid November, $2^{\text {nd }}$ crop mungbean (BARI Mung-6) were sown end of March and the third crop T. aman rice (var. BRRI dhan-33) seedlings (30 days old) were transplanted mid July.

\subsubsection{Intercultural Operation, Data Collection and Statistical Analysis}

Intercultural operations were done as and when required. The crops were harvested after maturity. Data on yields $(\mathrm{kg}$ $\mathrm{ha}^{-1}$ ) of all tested crops were recorded from whole plot technique. Analysis of variance (ANOVA) for the yields and different nutrient content was done following the principle of F-statistics and the mean values were separated by DMRT [7] 1984) using MSTAT-C software.

\subsection{Soil and Plant Samples Analysis}

Soil samples at $0-15 \mathrm{~cm}$ were collected before establishing the experiment and after completion of two cycles of the cropping system from each treatment plot. Plant samples (straw and grain) against each treatment plot were oven-dried at $70^{\circ} \mathrm{C}$ for $48 \mathrm{~h}$ and finely ground. The initial and final soil samples were analyzed for soil $\mathrm{pH}$ and organic matter by Nelson and Sommers [8] method; total $\mathrm{N}$ by Microkjeldahl method [9]; exchangeable $\mathrm{K}$ by $1 \mathrm{~N} \mathrm{NH}_{4} \mathrm{OAc}$ method [10]; available $\mathrm{P}$ by Olsen and Sommers [11] method; available $\mathrm{S}$ by turbidity method using $\mathrm{BaCl}_{2}$ [12]; available $\mathrm{Zn}$ by DTPA method [13]; available B by azomethine-H method [14]. Ground plant samples were digested with di-acid mixture $\left(\mathrm{HNO}_{3}-\mathrm{HClO}_{4}\right)(5: 1)$ as described by Piper [15] for the determination- concentration of N (Micro-Kjeldahl method), $\mathrm{P}$ (spectrophotometer method), $\mathrm{K}$ (atomic absorption spectrophotometer method), $\mathrm{S}$ (turbidity method using $\mathrm{BaCl}_{2}$ by spectrophotometer), $\mathrm{Zn}$ (atomic absorption spectrophotometer method) and B (spectrophotometer following azomethine-H method).

\subsection{Soil Solution, Rain and Irrigation Water Samples Analysis}

Soil solutions were collected at intervals of 15 days starting from the date after transplantation with the help of 50 $\mathrm{ml}$ plastic syringe and analyzed for determined nutrient leaching loss. Soil solution was collected at intervals of 15 days starting from the date after transplantation to harvest of rice crop with the help of $50 \mathrm{ml}$ plastic syringe. The samples were brought to the laboratory immediately after collection, filtered through Whatman No. 42 filter paper and preserved 
for the determination of $\mathrm{P}, \mathrm{K}, \mathrm{S}, \mathrm{Zn}$ and $\mathrm{B}$. Rain and irrigation water were collected and analyzed for determining the nutrients ( $\mathrm{P}, \mathrm{K}, \mathrm{S}, \mathrm{Zn}$ and $\mathrm{B}$ ) added to the soil. Soil solution, rain and irrigation water samples were analysed for concentration of $\mathrm{P}, \mathrm{K}, \mathrm{S}, \mathrm{Zn}$ and $\mathrm{B}$ same as plant samples analysis method.

\subsection{Nutrient Leaching Loss Estimation}

Nutrient loss was calculated from the results of percolation water and nutrient concentration in soil solution. In calculating percolation water $\left(\mathrm{L} \mathrm{m}^{-2}\right)$ the formula $\mathrm{Q}=$ $\mathrm{K}_{\mathrm{w}} \mathrm{AT} . \Delta \Psi_{\mathrm{h}} / \Delta \mathrm{z}$ given by Hanks and Ashcroft [16] was used. Where, $\mathrm{Q}=$ Quantity of water $\mathrm{K}_{\mathrm{w}}=$ Hydraulic conductivity, A $=$ Area, $\mathrm{T}=$ Time, $\mathrm{H}=$ Difference in hydraulic potential and $\mathrm{Z}=$ Difference between two points taking 0 to downward as negative. The hydraulic potential was again calculated by adding the component potentials as $\Psi_{\mathrm{h}}=\Psi_{\mathrm{m}}+\Psi_{\mathrm{p}}+\Psi_{\mathrm{z}}$ where $\mathrm{h}, \mathrm{m}, \mathrm{p}$, and $\mathrm{z}$ represent hydraulic, metric, pressure and gravitational potentials. Negative $Q$ was considered as downward movement of water.

\subsection{Nutrient Uptake and Apparent Balance Calculation}

Crop nutrient uptake was calculated from the nutrient $(\mathrm{N}$, $\mathrm{P}, \mathrm{K}, \mathrm{S}, \mathrm{Zn}$ and $\mathrm{B}$ ) concentration and the straw and grain yields [17]. Apparent nutrient balance for the mustardmungbean-T. aman rice cropping system (average of two years) was computed as the difference between nutrient input and output [6]. The inputs were supplied from (i) fertilizer (ii) rainfall and (iii) irrigation water and the outputs were estimated from crop uptake and leaching loss in a cycle.

\subsection{Physiological Efficiency (PE)}

Physiological efficiency (PE) was calculated according to
Equation-

$$
\mathrm{PE}=\frac{Y-Y_{0}}{U-U_{0}}
$$

Where $\mathrm{Y}$ is the yield of the fertilized plot, $\mathrm{Y}_{0}$ is the yield of the unfertilized plot, $U$ is the total nutrient uptake in above ground crop biomass with fertilized plot and $U_{0}$ is the total nutrient uptake in above ground crop biomass with unfertilized plot [6].

\subsection{Economic Analysis}

Added cost and added benefit were calculated. Besides, the gross return was calculated on the basis of different treatments which were directly related to the price of product. Cost of cultivation was involved with wage rate (land preparation, weeding, seed sowing and fertilizers application), pesticides, irrigation and fertilizers cost. Land used cost or rental value of land was not considered here. Marginal benefit cost ratio (MBCR) is the ratio of marginal or added benefit and cost. To compare different treatments combination with one control treatment the following equation was applied [18].

$$
\begin{aligned}
& =\frac{\text { Added benefit (over control) }}{\text { Added cost (over control) }} \\
& M B C R \text { (over control) }= \\
& \frac{\operatorname{Gross} \text { return }\left(T_{i}\right)-\operatorname{Gross} \text { return }\left(T_{0}\right)}{\operatorname{VC}\left(T_{i}\right)-\operatorname{VC}\left(T_{0}\right)}
\end{aligned}
$$

Where, $\mathrm{T}_{\mathrm{i}}=\mathrm{T}_{2}, \ldots \mathrm{T}_{4}$ treatments; $\mathrm{T}_{0}=$ Control treatment; $\mathrm{VC}=$ Variable cost; and

Gross return $=$ Yield $\times$ price

\begin{tabular}{|c|c|c|c|c|c|c|c|}
\hline \multirow{2}{*}{ Treatment } & \multicolumn{4}{|c|}{ Grain yield $\left(\mathrm{kg} \mathrm{ha}^{-1}\right)$} & \multicolumn{3}{|c|}{ Straw/stover yield $\left(\mathrm{kg} \mathrm{ha}^{-1}\right)$} \\
\hline & $1^{\text {st }}$ year & $2^{\text {nd }}$ year & mean & $\%$ of increase over control & $1^{\text {st }}$ year & $2^{\text {nd }}$ year & mean \\
\hline Control $\left(\mathrm{T}_{1}\right)$ & $\begin{array}{l}\text { Mustard } \\
818^{\mathrm{d}}\end{array}$ & $779^{d}$ & 798 & - & $2100^{\mathrm{d}}$ & $2020^{\mathrm{d}}$ & 2060 \\
\hline F. practice $\left(T_{2}\right)$ & $1124^{\mathrm{c}}$ & $1140^{\mathrm{c}}$ & 1132 & 42 & $2900^{c}$ & $2924^{\mathrm{c}}$ & 2912 \\
\hline $\operatorname{AEZ}\left(\mathrm{T}_{3}\right)$ & $1300^{\mathrm{b}}$ & $1330^{\mathrm{b}}$ & 1315 & 65 & $3610^{\mathrm{b}}$ & $3651^{\mathrm{b}}$ & 3630 \\
\hline $\mathrm{STB}\left(\mathrm{T}_{4}\right)$ & $1534^{\mathrm{a}}$ & $1552^{\mathrm{a}}$ & 1543 & 93 & $4172^{\mathrm{a}}$ & $4210^{\mathrm{a}}$ & 4191 \\
\hline $\mathrm{CV}(\%)$ & 3.55 & 3.27 & - & - & 2.94 & 2.97 & - \\
\hline & Mungbean & & & & & & \\
\hline Control $\left(\mathrm{T}_{1}\right)$ & $1049^{c}$ & $940^{c}$ & 995 & - & $2238^{\mathrm{d}}$ & $2110^{\mathrm{d}}$ & 2174 \\
\hline F. practice $\left(\mathrm{T}_{2}\right)$ & $1170^{\mathrm{b}}$ & $1242^{\mathrm{b}}$ & 1206 & 21 & $2341^{\mathrm{c}}$ & $2397^{\mathrm{c}}$ & 2369 \\
\hline $\operatorname{AEZ}\left(\mathrm{T}_{3}\right)$ & $1332^{\mathrm{a}}$ & $1386^{\mathrm{ab}}$ & 1359 & 37 & $2453^{\mathrm{b}}$ & $2468^{b}$ & 2461 \\
\hline $\mathrm{STB}\left(\mathrm{T}_{4}\right)$ & $1448^{\mathrm{a}}$ & $1530^{\mathrm{a}}$ & 1489 & 50 & $2557^{\mathrm{a}}$ & $2613^{a}$ & 2585 \\
\hline CV $(\%)$ & 4.99 & 6.17 & - & - & 2.88 & 3.74 & - \\
\hline $\mathrm{LSD}_{0.05}$ & 111 & 178 & - & - & 245 & 269 & - \\
\hline F. practice $\left(\mathrm{T}_{2}\right)$ & $3651^{\mathrm{b}}$ & $3700^{\mathrm{b}}$ & 3675 & 12 & $3769^{\mathrm{b}}$ & $3823^{\mathrm{b}}$ & 3796 \\
\hline $\operatorname{AEZ}\left(\mathrm{T}_{3}\right)$ & $3887^{b}$ & $3988^{\mathrm{ab}}$ & 3937 & 20 & $4027^{\mathrm{b}}$ & $4135^{\mathrm{ab}}$ & 4081 \\
\hline
\end{tabular}

\section{Result}

\subsection{Crops Yields}

Table 2. Effect of fertilizer management practices on grain and straw/stover yields of crops in mustard-mungbean-T. aman cropping system. 


\begin{tabular}{llllllll}
\hline \multirow{2}{*}{ Treatment } & \multicolumn{2}{l}{ Grain yield $\left(\mathbf{k g ~ h a}^{\mathbf{- 1}}\right)$} & & \multicolumn{3}{l}{ Straw/stover yield $\left(\mathbf{k g ~ h a} \mathbf{~}^{\mathbf{- 1}}\right)$} \\
\cline { 2 - 8 } & $\mathbf{1}^{\text {st }}$ year & $\mathbf{2}^{\text {nd }}$ year & mean & \% of increase over control & $\mathbf{1}^{\text {st }}$ year & $\mathbf{2}^{\text {nd }}$ year & mean \\
\hline STB $\left(T_{4}\right)$ & $4452^{\text {a }}$ & $4591^{\text {a }}$ & 4521 & 38 & $4633^{\text {a }}$ & $4768^{\text {a }}$ \\
CV $(\%)$ & 3.35 & 5.31 & - & - & 3.43 & 5.22 & - \\
$\mathrm{LSD}_{0.05}$ & 371 & 740 & - & - & 386 & 747 & - \\
\hline
\end{tabular}

Values within the same column with a common letter do not differ significantly $(\mathrm{P}<0.05)$

Nutrients management practices significantly influenced on grain and straw/stover yields of mustard, mungbean and $\mathrm{T}$. aman rice in both the years (Table 2). The grain yields (mean of two years) due to different fertlizer treatments ranged from 798 to $1543 \mathrm{~kg} \mathrm{ha}^{-1}$ in mustard, 995 to $1489 \mathrm{~kg} \mathrm{ha}^{-1}$ in mungbean and 3270 to $4521 \mathrm{~kg} \mathrm{ha}^{-1}$ in $\mathrm{T}$. aman rice. The control $\left(\mathrm{T}_{1}\right)$ treatment gave the lowest grain yield of 798, 995 and $3270 \mathrm{~kg} \mathrm{ha}^{-1}$ (mean of two years) in mustard, mungbean and $\mathrm{T}$. aman rice, respectively. The farmers practice of fertilizer application $\left(\mathrm{T}_{2}\right)$ increased grain yield to $1132 \mathrm{~kg} \mathrm{ha}^{-}$ ${ }^{1}$ in mustard, $1206 \mathrm{~kg} \mathrm{ha}^{-1}$ in mungbean and $3675 \mathrm{~kg} \mathrm{ha}^{-1}$ in T. aman rice. Fertilizer dose on AEZ basis $\left(\mathrm{T}_{3}\right)$ resulted in further yield increased of $1315 \mathrm{~kg} \mathrm{ha}^{-1}$ in mustard, $1359 \mathrm{~kg}$ $\mathrm{ha}^{-1}$ in mungbean and $3937 \mathrm{~kg} \mathrm{ha}^{-1}$ in $\mathrm{T}$. aman rice. The $\mathrm{T}_{4}$ treatment (soil test basis fertilizer application) gave the highest crop yields for all the test crops (Table 2). In case of straw/stover yield due to different treatments varied from 2060 to 4191,2174 to 2585 and 3378 to $4700 \mathrm{~kg} \mathrm{ha}^{-1}$ (mean of two years) in mustard, mungbean and $\mathrm{T}$. aman rice, respectively. The treatments normally statistically differed with one another and significantly highest value found in $T_{4}$ treatment and lowest in $\mathrm{T}_{1}$ treatment for all the test crops in both the years. The percent grain yields of mustard, mungbean and $\mathrm{T}$. aman rice increased over control due to different nutrient management practices were 42 to $93 \%, 21$ to $50 \%$ and 12 to $38 \%$, respectively (Table 2). Most of the yield contributing characters of mustard, mungbean and $\mathrm{T}$. aman rice highly responded to soil test basis fertilization $\left(\mathrm{T}_{4}\right)$ followed by AEZ basis fertilization $\left(\mathrm{T}_{3}\right)$ (data not showed).

\subsection{Nutrient Concentration and Defficiency Determination in Grain}

Grain nutrient concentration (mean of two years) of test crops- mustard, mungbean and T. aman and critical values are presented in Tables 3 . The nutrients concentration of mustard due to different fertilizer management practices ranged from 3.23 to $3.44 \% \mathrm{~N}, 0.42$ to $0.46 \% \mathrm{P}, 0.60$ to $0.64 \%$ $\mathrm{K}, 0.89$ to $0.92 \% \mathrm{~S}, 34.3$ to $37.6 \mathrm{ppm} \mathrm{Zn}$ and 28.2 to 32.8 $\mathrm{ppm} \mathrm{B}$. In case of mungbean, nutrient concentration varied in different treatment from 3.04 to $3.22 \% \mathrm{~N}, 0.21$ to $0.24 \% \mathrm{P}$, 1.33 to $1.39 \% \mathrm{~K}, 0.095$ to $0.115 \% \mathrm{~S}, 26.8$ to $31.0 \mathrm{ppm} \mathrm{Zn}$ and 15.2 to $21.5 \mathrm{ppm} \mathrm{B.} \mathrm{Further} \mathrm{in} \mathrm{T.} \mathrm{aman} \mathrm{rice,}$ concentration also ranged due to fertilizer treatments from 1.45 to $1.49 \% \mathrm{~N}, 0.20$ to $0.23 \% \mathrm{P}, 0.19$ to $0.22 \% \mathrm{~K}, 0.050$ to $0.075 \% \mathrm{~S}, 50.9$ to $52.9 \mathrm{ppm} \mathrm{Zn}$ and 21.6 to $24.1 \mathrm{ppm} \mathrm{B}$. Test crops nutrients values and critical values were compared due to different treatments (Table 3). Different nutrient management practices exhibited the deficiency of $\mathrm{N}$ in mustard, mungbean and $\mathrm{T}$. aman rice. The highest $\mathrm{N}$ deficiency showed $0.37 \%$ in mustard, $0.59 \%$ in mungbean, respectively for $\mathrm{T}_{1}$ treatment and $1.57 \%$ in $\mathrm{T}$. aman rice for $\mathrm{T}_{2}$ treatment. The lowest $\mathrm{N}$ deficiency found in all the test crops for $\mathrm{T}_{4}$ treatment. There was no $\mathrm{P}$ deficiency in mustard but mungbean and rice crop was showed minor deficency due to different treatment. Severe deficiency of K in mustard and $\mathrm{T}$. aman rice, but in mungbean showed minor $\mathrm{K}$ deficiency in all the treatment. The highest $\mathrm{K}$ deficiency was calculated from $T_{1}$ and lowest was $T_{4}$ treatment in all test crops (Table 3). Different treatment showed sufficiency of $\mathrm{S}$ in mustard, deficiency of $\mathrm{S}$ in mungbean and $\mathrm{T}$. aman rice. There was affected of $\mathrm{Zn}$ in mustard and less affected of $\mathrm{Zn}$ in mungbean and $\mathrm{T}$. aman rice due to different treatments. There was no deficiency of $B$ in mustard for $T_{3}$ and $T_{4}$ treatment. Mungbean showed deficiency of $\mathrm{B}$ in all the treatments while the highest $\mathrm{B}$ deficiency found in $\mathrm{T}_{1}$ and lowest in $\mathrm{T}_{4}$ treatment. The $3^{\text {rd }}$ crop $\mathrm{T}$. aman rice crops showed B sufficiency in all the treatments (Table 3).

Table 3. Comparison between the grain nutrients concentration of mustard, mungbean and T. aman with critical values due to different fertilizer management practices.

\begin{tabular}{lllllll}
\hline Treatment & $\mathbf{N}$ & $\mathbf{P}$ & $\mathbf{K}$ & $\mathbf{S}$ & $\mathbf{Z n}$ & $\mathbf{B}$ \\
\hline Mustard & $\mathbf{( \% )}$ & & & \multicolumn{3}{c}{$\mathbf{p p m}$} \\
\hline Control $\left(\mathrm{T}_{1}\right)$ & 3.23 & 0.42 & 0.60 & 0.89 & 34.3 & 28.2 \\
F. practice $\left(\mathrm{T}_{2}\right)$ & 3.34 & 0.43 & 0.63 & 0.90 & 34.4 & 28.3 \\
AEZ $\left(\mathrm{T}_{3}\right)$ & 3.37 & 0.45 & 0.64 & 0.91 & 37.0 & 32.6 \\
STB $\left(\mathrm{T}_{4}\right)$ & 3.44 & 0.46 & 0.64 & 0.92 & 37.6 & 32.8 \\
Critical value & 3.60 & 0.25 & 1.60 & 0.13 & 50.0 & 30.0 \\
Mungbean & & & & & & \\
Control $\left(\mathrm{T}_{1}\right)$ & 3.04 & 0.21 & 1.33 & 0.095 & 26.8 & 15.2 \\
F. practice $\left(\mathrm{T}_{2}\right)$ & 3.16 & 0.22 & 1.36 & 0.105 & 26.9 & 15.9 \\
AEZ $\left(\mathrm{T}_{3}\right)$ & 3.18 & 0.23 & 1.37 & 0.115 & 30.5 & 20.5 \\
STB $\left(\mathrm{T}_{4}\right)$ & 3.22 & 0.24 & 1.39 & 0.115 & 31.0 & 21.5 \\
Critical value & 3.63 & 0.26 & 1.75 & 0.20 & 35.0 & 27.0 \\
T. aman rice & & & & & & \\
Control $\left(\mathrm{T}_{1}\right)$ & 1.45 & 0.20 & 0.19 & 0.050 & 50.9 & 21.6 \\
F. practice $\left(\mathrm{T}_{2}\right)$ & 1.43 & 0.21 & 0.20 & 0.055 & 51.2 & 22.3 \\
AEZ $\left(\mathrm{T}_{3}\right)$ & 1.45 & 0.22 & 0.21 & 0.065 & 52.6 & 23.2 \\
STB $\left(\mathrm{T}_{4}\right)$ & 1.49 & 0.23 & 0.22 & 0.075 & 52.9 & 24.1 \\
Critical value & 3.00 & 0.23 & 1.20 & 0.15 & 60.0 & 15.0 \\
\hline
\end{tabular}

Nutrient critical values source: [19, 20].

\subsection{Nutrient Uptake}

Nutrient management practices had significant effect on the uptake of N, P, K, S, Zn and B by the crops in mustardmungbean-T. aman rice cropping system in both the years (Table 4). Fertlizer application on soil test basis $\left(T_{4}\right)$ showed significantly higher nutrient uptake by mustard, mungbean and $\mathrm{T}$. aman rice in both the years. The nutrient uptake followed the order: $\mathrm{N}>\mathrm{K}>\mathrm{S}>\mathrm{P}>\mathrm{Zn}>\mathrm{B}$. The lower nutrient uptake was observed in control $\left(\mathrm{T}_{1}\right)$ treatment by all test crops. The total uptake of nutrients by crops (mustard+mungbean+T. aman) ranged from 167-278 kg N 
$\mathrm{ha}^{-1}, 16.7-30.7 \mathrm{~kg} \mathrm{P} \mathrm{ha}{ }^{-1}, 129-199 \mathrm{~kg} \mathrm{~K} \mathrm{ha}^{-1}, 17.6-35.5 \mathrm{~kg} \mathrm{~S}$ $\mathrm{ha}^{-1}, 0.49-0.81 \mathrm{~kg} \mathrm{Zn} \mathrm{ha}^{-1}$ and 0.28-0.48 $\mathrm{kg} \mathrm{B} \mathrm{ha}^{-1}$ (Figures 1 \& 2).

Maximum N uptake was found in STB (278 $\left.\mathrm{kg} \mathrm{ha}^{-1} \mathrm{yr}^{-1}\right)$ followed by AEZ $\left(\mathrm{T}_{3}\right)$. Minimum uptake was estimated in control $\left(\mathrm{T}_{1}\right)$. The treatment STB showed highest phosphorus uptake (30.7 $\left.\mathrm{kg} \mathrm{ha}^{-1} \mathrm{yr}^{-1}\right)$ followed by AEZ (25.1 kg ha $\left.{ }^{-1} \mathrm{yr}^{-1}\right)$. The lowest uptake was found in control $\left(16.7 \mathrm{~kg} \mathrm{ha}^{-1} \mathrm{yr}^{-1}\right)$. Due to different treatments the highest total potassium uptake was found in STB (199 $\left.\mathrm{kg} \mathrm{ha}^{-1} \mathrm{yr}^{-1}\right)$ followed by AEZ (174 $\mathrm{kg} \mathrm{ha}^{-1} \mathrm{yr}^{-1}$ for all test crops. The lowest $\mathrm{K}$ uptake was observed in control $\left(129 \mathrm{~kg} \mathrm{ha}^{-1} \mathrm{yr}^{-1}\right)$. Among the treatments, maximum S uptake was observed in STB (35.5 $\left.\mathrm{kg} \mathrm{ha}^{-1} \mathrm{yr}^{-1}\right)$ followed by AEZ ( $\left.30.1 \mathrm{~kg} \mathrm{ha}^{-1} \mathrm{yr}^{-1}\right)$ and the minimum was in control treatment $\left(17.6 \mathrm{~kg} \mathrm{ha}^{-1} \mathrm{yr}^{-1}\right)$. The uptake of other nutrients $(\mathrm{Zn}$ and $\mathrm{B})$ due to different nutrients management practices followed almost the same trend of $\mathrm{N}$ uptake (Figures 1 \& 2).

Table 4. Effect of nutrient management practices on nutrient uptake ( $\mathrm{kg} \mathrm{ha}^{-1}$ ) by mustard-mungbean-T. aman (grain + straw/stover) cropping system.

\begin{tabular}{|c|c|c|c|c|c|c|c|c|c|c|c|c|}
\hline \multirow{2}{*}{ Treatment } & \multicolumn{2}{|l|}{$\mathbf{N}$} & \multicolumn{2}{|l|}{$\mathbf{P}$} & \multicolumn{2}{|l|}{$\mathbf{K}$} & \multicolumn{2}{|l|}{$\mathbf{S}$} & \multicolumn{2}{|l|}{$\mathrm{Zn}$} & \multicolumn{2}{|l|}{ B } \\
\hline & $1^{\text {st }} \mathrm{yr}$ & $2^{\text {nd }} y r$ & $1^{\text {st }} \mathrm{yr}$ & $2^{\text {nd }} y r$ & $1^{\text {st }} \mathrm{yr}$ & $2^{\text {nd }} y r$ & $1^{\text {st }} \mathrm{yr}$ & $2^{\text {nd }} y r$ & $1^{\text {st }} \mathrm{yr}$ & $2^{\text {nd }} y r$ & $1^{\text {st }} \mathrm{yr}$ & $2^{\text {nd }} \mathrm{yr}$ \\
\hline & \multicolumn{12}{|c|}{ Mustard } \\
\hline Control $\left(\mathrm{T}_{1}\right)$ & $47.0^{\mathrm{d}}$ & $44.3^{\mathrm{d}}$ & $4.15^{\mathrm{d}}$ & $3.60^{\mathrm{d}}$ & $29.4^{\mathrm{d}}$ & $27.8^{\mathrm{d}}$ & $12.4^{\mathrm{d}}$ & $11.5^{\mathrm{d}}$ & $0.09^{\mathrm{c}}$ & $0.08^{\mathrm{c}}$ & $0.07^{\mathrm{c}}$ & $0.06^{\mathrm{c}}$ \\
\hline F. practice $\left(\mathrm{T}_{2}\right)$ & $67.2^{\mathrm{c}}$ & $67.5^{\mathrm{c}}$ & $6.12^{\mathrm{c}}$ & $5.72^{\mathrm{c}}$ & $41.4^{\mathrm{c}}$ & $41.8^{\mathrm{c}}$ & $17.5^{\mathrm{c}}$ & $17.3^{\mathrm{c}}$ & $0.12^{\mathrm{bc}}$ & $0.12^{\mathrm{bc}}$ & $0.10^{\mathrm{b}}$ & $0.10^{\text {bc }}$ \\
\hline $\operatorname{AEZ}\left(T_{3}\right)$ & $82.2^{\mathrm{b}}$ & $82.7^{\mathrm{b}}$ & $7.81^{\mathrm{b}}$ & $7.33^{\mathrm{b}}$ & $51.3^{\mathrm{b}}$ & $52.2^{\mathrm{b}}$ & $21.4^{\mathrm{b}}$ & $21.1^{\mathrm{b}}$ & $0.15^{\mathrm{b}}$ & $0.16^{\mathrm{b}}$ & $0.13^{\mathrm{ab}}$ & $0.14^{\mathrm{b}}$ \\
\hline $\operatorname{STB}\left(\mathrm{T}_{4}\right)$ & $99.6^{\mathrm{a}}$ & $100^{\mathrm{a}}$ & $9.73^{\mathrm{a}}$ & $9.14^{\mathrm{a}}$ & $60.0^{\mathrm{a}}$ & $60.7^{\mathrm{a}}$ & $24.9^{\mathrm{a}}$ & $24.2^{\mathrm{a}}$ & $0.18^{\mathrm{a}}$ & $0.19^{\mathrm{a}}$ & $0.16^{\mathrm{a}}$ & $0.17^{\mathrm{a}}$ \\
\hline \multirow[t]{2}{*}{$\mathrm{LSD}_{0.05}$} & 3.88 & 3.39 & 1.10 & 1.23 & 4.89 & 4.34 & 1.08 & 1.12 & 0.019 & 0.02 & 0.02 & 0.019 \\
\hline & \multicolumn{12}{|c|}{ Mungbean } \\
\hline Control $\left(\mathrm{T}_{1}\right)$ & $59.1^{\mathrm{d}}$ & $55.1^{\mathrm{d}}$ & $4.50^{\mathrm{c}}$ & $3.72^{\mathrm{d}}$ & $47.6^{\mathrm{d}}$ & $44.9^{\mathrm{d}}$ & $2.13^{\mathrm{c}}$ & $1.74^{\mathrm{c}}$ & $0.07^{\mathrm{c}}$ & $0.06^{\mathrm{c}}$ & $0.06^{\mathrm{b}}$ & $0.05^{\mathrm{c}}$ \\
\hline F. practice $\left(T_{2}\right)$ & $65.6^{\mathrm{c}}$ & $65.7^{\mathrm{c}}$ & $5.12^{\mathrm{bc}}$ & $4.51^{\mathrm{c}}$ & $51.8^{\mathrm{c}}$ & $51.4^{\mathrm{c}}$ & $2.61^{\mathrm{bc}}$ & $2.33^{\mathrm{bc}}$ & $0.08^{\mathrm{bc}}$ & $0.07^{\mathrm{bc}}$ & $0.07^{\mathrm{b}}$ & $0.08^{\mathrm{bc}}$ \\
\hline $\operatorname{AEZ}\left(\mathrm{T}_{3}\right)$ & $72.4^{\mathrm{b}}$ & $74.2^{\mathrm{b}}$ & $5.77^{\mathrm{b}}$ & $5.44^{\mathrm{b}}$ & $55.6^{\mathrm{b}}$ & $56.8^{\mathrm{b}}$ & $3.23^{\mathrm{ab}}$ & $2.95^{\mathrm{b}}$ & $0.09^{\mathrm{b}}$ & $0.11^{\mathrm{b}}$ & $0.09^{\mathrm{a}}$ & $0.10^{\mathrm{a}}$ \\
\hline $\operatorname{STB}\left(\mathrm{T}_{4}\right)$ & $82.0^{\mathrm{a}}$ & $85.6^{\mathrm{a}}$ & $6.71^{\mathrm{a}}$ & $6.23^{\mathrm{a}}$ & $61.4^{\mathrm{a}}$ & $63.0^{\mathrm{a}}$ & $3.81^{\mathrm{a}}$ & $3.44^{\mathrm{a}}$ & $0.10^{\mathrm{a}}$ & $0.12^{\mathrm{a}}$ & $0.10^{\mathrm{a}}$ & $0.11^{\mathrm{a}}$ \\
\hline CV (\%) & 2.94 & 2.19 & 6.34 & 2.41 & 2.86 & 2.54 & 6.77 & 4.82 & 7.34 & 8.22 & 8.87 & 7.73 \\
\hline $\mathrm{LSD}_{0.05}$ & \multicolumn{12}{|c|}{ T. aman } \\
\hline Control $\left(\mathrm{T}_{1}\right)$ & $67.0^{\mathrm{d}}$ & $62.3^{\mathrm{d}}$ & $9.51^{\mathrm{d}}$ & $8.02^{\mathrm{c}}$ & $55.5^{\mathrm{d}}$ & $51.6^{\mathrm{c}}$ & $4.44^{\mathrm{d}}$ & $2.92^{\mathrm{d}}$ & $0.35^{\mathrm{c}}$ & $0.32^{\mathrm{d}}$ & $0.15^{\mathrm{b}}$ & $0.14^{\mathrm{c}}$ \\
\hline F. practice $\left(\mathrm{T}_{2}\right)$ & $74.1^{\mathrm{c}}$ & $74.3^{\mathrm{c}}$ & $11.0^{\mathrm{c}}$ & $10.4^{\mathrm{bc}}$ & $2^{c}$ & $60.6^{\mathrm{bc}}$ & $5.21^{\mathrm{c}}$ & $4.14^{\mathrm{c}}$ & $0.39^{\mathrm{bc}}$ & $0.38^{\mathrm{c}}$ & $0.17^{\mathrm{b}}$ & $0.18^{b c}$ \\
\hline $\operatorname{AEZ}\left(T_{3}\right)$ & $80.2^{\mathrm{b}}$ & $81.1^{\mathrm{b}}$ & $12.6^{\mathrm{b}}$ & $11.3^{\mathrm{b}}$ & $65.7^{\mathrm{b}}$ & $66.3^{\mathrm{b}}$ & $6.35^{\mathrm{b}}$ & $5.29^{\mathrm{b}}$ & $0.43^{\mathrm{b}}$ & $0.44^{\mathrm{a}}$ & $0.19^{\mathrm{ab}}$ & $0.19^{\mathrm{b}}$ \\
\hline $\operatorname{STB}\left(\mathrm{T}_{4}\right)$ & $94.3^{\mathrm{a}}$ & $95.2^{\mathrm{a}}$ & $15.3^{\mathrm{a}}$ & $14.4^{\mathrm{a}}$ & $76.5^{\mathrm{a}}$ & $76.9^{\mathrm{a}}$ & $7.73^{\mathrm{a}}$ & $6.92^{\mathrm{a}}$ & $0.51^{\mathrm{a}}$ & $0.52^{\mathrm{a}}$ & $0.22^{\mathrm{a}}$ & $0.23^{\mathrm{a}}$ \\
\hline CV (\%) & 3.24 & 2.55 & 4.77 & 5.22 & 5.14 & 6.54 & 5.86 & 6.21 & 7.33 & 4.25 & 9.74 & 8.41 \\
\hline $\mathrm{LSD}_{0.05}$ & 4.31 & 3.84 & 1.08 & 1.12 & 5.21 & 5.24 & 1.04 & 0.92 & 0.02 & 0.019 & 0.02 & 0.019 \\
\hline
\end{tabular}

Values within the same column with a common letter do not differ significantly $(\mathrm{P}<0.05)$.

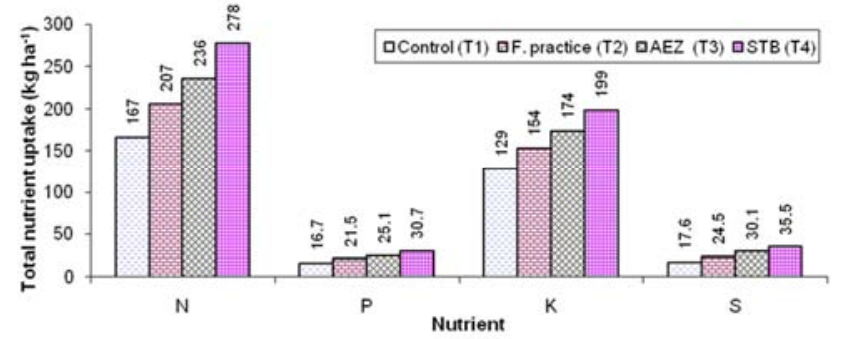

Figure 1. Effect of fertilizer management practices on total uptake of nutrients by crops under mustard-mungbean-T. aman cropping system.

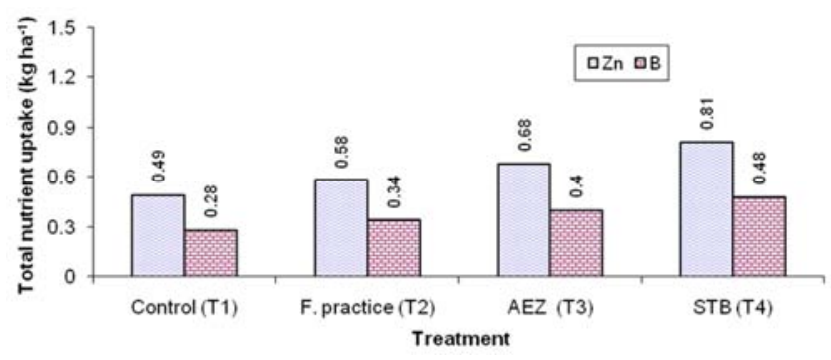

Figure 2. Effect of fertilizer management practices on total uptake of zinc and boron by crops under mustard-mungbean-T. aman cropping system.

\subsection{Physiological Efficiency of Nutrient}

Physiological efficiency (PE) of nutrient was calculated from the ratio of economic yield (yield of fertilized plot minus yield of unfertilized plot) and nutrient uptake by the above ground biomass of crop (nutrient uptake of fertilized plot minus nutrient uptake of unfertilized plot). Physiological efficiency of $\mathrm{N}$ in mustard, mungbean and T. aman were 13.6 to $15.2,17.4$ to 21.3 and 40.3 to $42.1 \mathrm{~kg} \mathrm{~kg}^{-1}$, respectively, in the first year and 13.9 to $15.6,19.3$ to 28.5 and 42.5 to $42.7 \mathrm{~kg} \mathrm{~kg}^{-1}$, respectively in the second year (Table 5). Physiological efficiency of $\mathrm{N}$ for all test crops had a higher value in second year compared to the first year. Among the treatments, physiological efficiency of $\mathrm{N}$ showed comperatively higher value in $\mathrm{T}_{2}$ treatment over the others treatment in both the years. Mustard, mungbean and $\mathrm{T}$. aman rice showed physiological efficiency of $\mathrm{P}$ due to different treatment varied from 128 to 155,181 to 223 and 173 to $201 \mathrm{~kg}$ $\mathrm{kg}^{-1}$, respectively in first year and 140 to 170,235 to 382 and 215 to $244 \mathrm{~kg} \mathrm{~kg}^{-1}$, respectively in the second year. Physiological efficiency of $\mathrm{P}$ for all the crops had a higher value in second year compared to the first year. In case of physiological efficiency of $\mathrm{K}$ and $\mathrm{S}$ in mustard, mungbean and 
T. aman showed the similar trend as physiological efficiency of $\mathrm{N}$ and $\mathrm{P}$ in both the years (Table 5). Mustard due to different nutrient management practices had physiological efficiency of $\mathrm{Zn}$ and $\mathrm{B}$ ranged from 7.96 to $10.2 \& 7.96$ to $10.2 \mathrm{~kg} \mathrm{~g}^{-1}$, respectively in first year and similar trend also had in second year. Physiological efficiency of $\mathrm{Zn}$ and $\mathrm{B}$ in mungbean varied from 12.1 to 14.2 and 9.43 to $12.1 \mathrm{~kg} \mathrm{~g}^{-1}$, respectively in first year and 8.92 to 30.2 and 8.92 to $10.1 \mathrm{~kg} \mathrm{~g}^{-1}$, respectively in second year. Physiological efficiency of $\mathrm{Zn}$ and $\mathrm{B}$ in $\mathrm{T}$. aman rice found 6.69 to 7.48 and 13.4 to $15.7 \mathrm{~kg} \mathrm{~g}^{-1}$, respectively in first year and 6.67 to 8.53 and 12.8 to $16.0 \mathrm{~kg} \mathrm{~g}^{-1}$, respectively in second year. Among the different treatment, physiological efficiency of $\mathrm{Zn}$ and $\mathrm{B}$ observed higher in $\mathrm{T}_{1}$ treatment in mustard and mungbean at both the years except $\mathrm{PE}$ of $\mathrm{Zn}$ in mungbean at $1^{\text {st }}$ year but it was higher $\left(14.2 \mathrm{~kg} \mathrm{~g}^{-1}\right)$ in $T_{3}$ treatment (Table 5).

Table 5. Effect of fertilizer management practices on physiological efficiency of nutrient in crops of mustard-mungbean-T. aman rice cropping system.

\begin{tabular}{|c|c|c|c|c|c|c|c|c|c|c|c|c|}
\hline \multirow{4}{*}{ Treatment } & \multicolumn{12}{|c|}{ Physiological efficiency } \\
\hline & \multicolumn{8}{|c|}{$\mathrm{kg} \mathrm{kg}^{-1}$} & \multicolumn{4}{|c|}{$\mathrm{kg} \mathrm{g}^{-1}$} \\
\hline & \multicolumn{2}{|l|}{$\mathbf{N}$} & \multicolumn{2}{|l|}{$\mathbf{P}$} & \multicolumn{2}{|l|}{$\mathbf{K}$} & \multicolumn{2}{|l|}{$\mathbf{S}$} & \multicolumn{2}{|l|}{$\mathbf{Z n}$} & \multicolumn{2}{|l|}{ B } \\
\hline & $1^{\text {st }} \mathrm{yr}$ & $2^{\text {nd }} y r$ & $1^{\text {st }} \mathrm{yr}$ & $2^{\text {nd }} y r$ & $1^{\text {st }} \mathrm{yr}$ & $2^{\text {nd }} y r$ & $1^{\text {st }} \mathrm{yr}$ & $2^{\text {nd }} y r$ & $1^{\text {st }} \mathrm{yr}$ & $2^{\text {nd }} y r$ & $1^{\text {st }} \mathrm{yr}$ & $2^{\text {nd }} y r$ \\
\hline & \multicolumn{12}{|c|}{ Mustard } \\
\hline Control $\left(\mathrm{T}_{1}\right)$ & - & - & - & - & - & - & - & - & - & - & - & - \\
\hline F. practice $\left(T_{2}\right)$ & 15.2 & 15.6 & 155 & 170 & 25.5 & 25.8 & 60.0 & 62.2 & 10.2 & 9.03 & 10.2 & 9.03 \\
\hline $\operatorname{AEZ}\left(\mathrm{T}_{3}\right)$ & 13.7 & 14.4 & 132 & 148 & 22.0 & 22.6 & 53.6 & 57.4 & 8.03 & 6.89 & 8.03 & 6.89 \\
\hline $\operatorname{STB}\left(\mathrm{T}_{4}\right)$ & \multicolumn{12}{|c|}{ Mungbean } \\
\hline Control $\left(\mathrm{T}_{1}\right)$ & - & - & - & - & - & - & - & - & - & - & - & - \\
\hline F. practice $\left(\mathrm{T}_{2}\right)$ & 18.6 & 28.5 & 195 & 382 & 28.81 & 46.5 & 252 & 512 & 12.1 & 30.2 & 12.1 & 10.1 \\
\hline $\operatorname{AEZ}\left(\mathrm{T}_{3}\right)$ & 21.3 & 23.4 & 223 & 259 & 35.38 & 37.5 & 257 & 369 & 14.2 & 8.92 & 9.43 & 8.92 \\
\hline \multirow[t]{2}{*}{$\mathrm{STB}\left(\mathrm{T}_{4}\right)$} & 17.4 & 19.3 & 181 & 235 & 28.91 & 32.6 & 238 & 347 & 13.3 & 9.83 & 9.98 & 9.83 \\
\hline & \multicolumn{12}{|c|}{ T. aman } \\
\hline Control $\left(\mathrm{T}_{1}\right)$ & - & - & - & - & - & - & - & - & - & - & - & - \\
\hline $\operatorname{AEZ}\left(\mathrm{T}_{3}\right)$ & 40.5 & 42.6 & 173 & 244 & 52.4 & 54.4 & 280 & 338 & 6.69 & 6.67 & 13.4 & 16.0 \\
\hline $\mathrm{STB}\left(\mathrm{T}_{4}\right)$ & 40.3 & 42.5 & 190 & 220 & 52.4 & 55.5 & 334 & 351 & 6.88 & 7.02 & 15.7 & 15.6 \\
\hline
\end{tabular}

\subsection{Leaching of Nutrients}

Leaching loss was estimated only to T. aman rice. Due to dry land condition, leaching loss was not considered during mustard and mungbean cultivation. Nutrient loss was calculated from the results of percolation water and nutrient concentration in soil solution. Nitrogen loss was ignored due to very low concentration in soil solution. Different nutrient management practices favoured the loss of $\mathrm{P}, \mathrm{K}, \mathrm{S}, \mathrm{Zn}$ and B element through leaching. The loss of nutrients (average of two years) through leaching ranged from 0.18 to $0.41 \mathrm{~kg} \mathrm{P}$ $\mathrm{ha}^{-1}, 2.33$ to $8.04 \mathrm{~kg} \mathrm{~K} \mathrm{ha}^{-1}, 1.13$ to $2.83 \mathrm{~kg} \mathrm{~S}^{-1}, 0.03$ to $0.09 \mathrm{~kg} \mathrm{Zn} \mathrm{ha}^{-1}$ and 0.05 to $0.28 \mathrm{~kg} \mathrm{~B} \mathrm{ha}^{-1}$. The highest and lowest values of nutrients loss were always found in $\mathrm{T}_{4}$ and $\mathrm{T}_{1}$ treatments (Table 6).

Table 6. Leaching of nutrients due to different fertilizer management practices under mustard-mungbean-T. aman cropping system (average of two years).

\begin{tabular}{llllll}
\hline \multirow{2}{*}{ Treatment } & P & K & S & Zn & B \\
\cline { 2 - 6 } & kg ha $^{-\mathbf{1}}$ & & & & \\
\hline Control $\left(\mathrm{T}_{1}\right)$ & 0.18 & 2.33 & 1.13 & 0.03 & 0.05 \\
F. practice $\left(\mathrm{T}_{2}\right)$ & 0.36 & 5.94 & 1.81 & 0.03 & 0.05 \\
AEZ $\left(\mathrm{T}_{3}\right)$ & 0.40 & 7.64 & 2.28 & 0.08 & 0.21 \\
STB $\left(\mathrm{T}_{4}\right)$ & 0.41 & 8.04 & 2.83 & 0.09 & 0.28 \\
\hline
\end{tabular}

\subsection{Total Input of Nutrients}

The nutrient input was mainly from fertilizer but in this estimate, the nutrients supply from fertilizer, rainfall and irrigation under mustard-mungbean-T. aman rice cropping system. BNF was not considerd. Total input of nitrogen was 166 to $190 \mathrm{~kg} \mathrm{~N} \mathrm{ha}^{-1}$ of which the major part was added through fertilizer application, except in control treatment. Phosphorus input ranged from 0.48 to $56.5 \mathrm{~kg} \mathrm{ha}^{-1} \mathrm{yr}^{-1}$ and $\mathrm{K}$ from 9.04 to $119 \mathrm{~kg} \mathrm{ha}^{-1} \mathrm{yr}^{-1}$. The $\mathrm{S}$ input varied from 5.49 to $41.5 \mathrm{~kg} \mathrm{ha}^{-1} \mathrm{yr}^{-1}$. Input of $\mathrm{Zn}$ ranged from 0.14 to $4.14 \mathrm{~kg} \mathrm{ha}^{-1} \mathrm{yr}^{-1}$. Boron input was estimated 0.34 to $4.35 \mathrm{~kg} \mathrm{ha}^{-1} \mathrm{yr}^{-1}$ (Table 7).

Table 7. Total input of $N, P, K, S, Z n$ and $B$ from fertilizer, rainfall and irrigation under mustard-mungbean-T. aman rice cropping system.

\begin{tabular}{lllllll}
\hline \multirow{2}{*}{ Treatment } & $\mathbf{N}$ & $\mathbf{P}$ & $\mathbf{K}$ & $\mathbf{S}$ & $\mathbf{Z n}$ & $\mathbf{B}$ \\
\cline { 2 - 7 } & kg ha $^{\mathbf{- 1}}$ & & & & & \\
\hline Control $\left(\mathrm{T}_{1}\right)$ & 0.00 & 0.48 & 9.04 & 5.49 & 0.14 & 0.34 \\
F. practice $\left(\mathrm{T}_{2}\right)$ & 166 & 26.5 & 53.0 & 5.49 & 0.14 & 0.34 \\
AEZ $\left(\mathrm{T}_{3}\right)$ & 157 & 34.5 & 97.0 & 28.4 & 1.14 & 1.35 \\
STB $\left(\mathrm{T}_{4}\right)$ & 190 & 56.5 & 119 & 41.5 & 4.14 & 4.35 \\
\hline
\end{tabular}

\subsection{Total Output of Nutrients}

The output of nutrients (mean of two years) ranged from 167 to $278 \mathrm{~kg} \mathrm{~N}^{-1}, 17.0$ to $31.0 \mathrm{~kg} \mathrm{P}^{-1}, 131$ to $207 \mathrm{~kg} \mathrm{~K}$ $\mathrm{ha}^{-1}, 19.0$ to $38.0 \mathrm{~kg} \mathrm{~S}^{-1}, 0.52$ to $0.90 \mathrm{~kg} \mathrm{Zn} \mathrm{ha}^{-1}$ and 0.35 to $0.76 \mathrm{~kg} \mathrm{~B} \mathrm{ha}^{-1}$. The highest outputs of all nutrients were found in $T_{4}$ treatment and the lowest were in control $\left(T_{1}\right)$ treatment (Table 8).

Table 8. Effect of fertilizer management practices on total output (crop uptake and leaching loss) of nutrients by mustard-mungbean-T. aman rice cropping system (mean of two years).

\begin{tabular}{lllllll}
\hline \multirow{2}{*}{ Treatment } & $\mathbf{N}$ & $\mathbf{P}$ & $\mathbf{K}$ & $\mathbf{S}$ & $\mathbf{Z n}$ & $\mathbf{B}$ \\
\cline { 2 - 7 } & $\mathbf{k g ~ h a}^{-1}$ & & & & & \\
\hline Control $\left(\mathrm{T}_{1}\right)$ & 167 & 17 & 131 & 19 & 0.52 & 0.35 \\
\hline
\end{tabular}




\begin{tabular}{lllllll}
\hline \multirow{2}{*}{ Treatment } & N & P & K & S & Zn & B \\
\cline { 2 - 7 } & kg ha $^{-\mathbf{1}}$ & & & & & \\
\hline F. practice $\left(\mathrm{T}_{2}\right)$ & 207 & 22 & 160 & 26 & 0.61 & 0.39 \\
AEZ $\left(\mathrm{T}_{3}\right)$ & 236 & 25 & 182 & 32 & 0.77 & 0.63 \\
STB $\left(\mathrm{T}_{4}\right)$ & 278 & 31 & 207 & 38 & 0.90 & 0.76 \\
\hline
\end{tabular}

\subsection{Apparent Nutrients Balance}

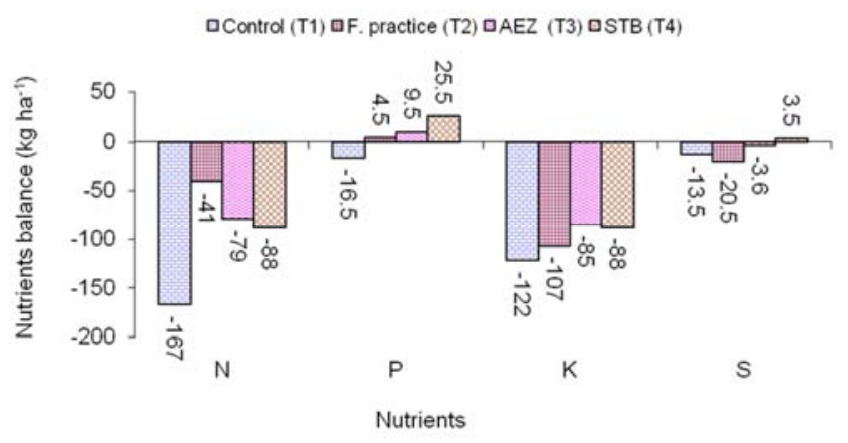

Figure 3. Effect of nutrient management practices on apparent nutrient balance of $N, P, K$ and $S$ in soil under mustard-mungbean-T. aman cropping system.

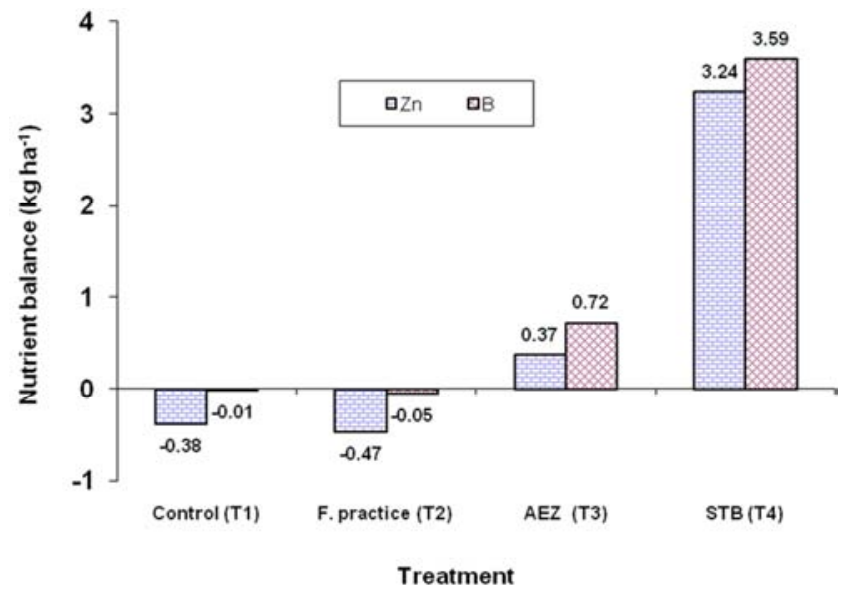

Figure 4. Effect of nutrient management practices on apparent balance of zinc and boron in soil under mustard-mungbean-T. aman cropping system.

An apparent nutrient balance was calculated considering the amount of added nutrient through fertilizer, rain, irrigation water minus the amount of nutrient removed by crops and leaching loss. However, the nutrient balance did not account for the addition of $\mathrm{N}$ from rainfall, irrigation water, or gaseous losses or BNF. Apparent balance of N, P, $\mathrm{K}, \mathrm{S}, \mathrm{Zn}$ and B are shown in Figures 3 \& 4. Apparent balance was mainly affected by different nutrient management practices. The apparent balance of $\mathrm{N}$ was negative in all the treatment and the depletion ranged from -41.0 to $-167 \mathrm{~kg} \mathrm{~N}$ $\mathrm{ha}^{-1} \mathrm{yr}^{-1}$. In case of $\mathrm{P}$ balance which was negative $(-16.5 \mathrm{~kg}$ $\left.\mathrm{ha}^{-1} \mathrm{yr}^{-1}\right)$ in control treatment $\left(\mathrm{T}_{1}\right)$ and the $\mathrm{P}$ balance was positive (4.50 to $25.5 \mathrm{~kg} \mathrm{ha}^{-1} \mathrm{yr}^{-1}$ ) in all other treatment where $\mathrm{P}$ containing fertilizer was utilized. The balance of $\mathrm{K}$ was negative in all the treatments where the $\mathrm{K}$ mining ranged from -85.0 to $-122 \mathrm{~kg} \mathrm{~K} \mathrm{ha}^{-1} \mathrm{yr}^{-1}$. The highest $\mathrm{K}$ mining was recorded from control treatment followed by farmer practice $\left(\mathrm{T}_{2}\right)$ and the lowest $\mathrm{K}$ mining was found in AEZ basis fertilizer treatment $\left(\mathrm{T}_{3}\right)$.

The balance for $\mathrm{S}$ was showed negative value in control, farmers practice and AEZ basis fertilizer treatments ranged from -3.60 to $-20.5 \mathrm{~kg} \mathrm{ha}^{-1} \mathrm{yr}^{-1}$ while STB treatment observed positive (3.50 kg ha $\left.{ }^{-1} \mathrm{yr}^{-1}\right)$. The negative $\mathrm{Zn}$ and $\mathrm{B}$ balance was observed in control and farmers practice treatments ranged from -.38 to -0.47 and -0.01 to $-0.05 \mathrm{~kg}$ $\mathrm{ha}^{-1} \mathrm{yr}^{-1}$, respectively. Remaining treatments showed positive balance ranged from 0.37 to 3.24 and 0.72 to $3.59 \mathrm{~kg} \mathrm{ha}^{-1} \mathrm{yr}^{-}$ 1 , respectively. The highest positive balance of $\mathrm{Zn}(3.24 \mathrm{~kg}$ $\mathrm{ha}^{-1} \mathrm{yr}^{-1}$ ) and $\mathrm{B}$ (3.59 $\left.\mathrm{kg} \mathrm{ha}^{-1} \mathrm{yr}^{-1}\right)$ was recorded from STB $\left(\mathrm{T}_{4}\right)$ treatment.

\subsection{Soil Fertility}

Initial soil samples were collected from the experimental field and post harvest soil samples were also collected from each treated plot after two cycles of mustard-mungbean-T. aman rice cropping system for analyzing different soil properties viz. soil $\mathrm{pH}$, organic matter, total $\mathrm{N}$ and available $\mathrm{P}, \mathrm{K}, \mathrm{S}, \mathrm{Zn}$ and $\mathrm{B}$. The initial and post harvest soil results are presented in Table 9. Initially the soil $\mathrm{pH}$ was 6.3 , but after completion of two crop cycles and incorporation of mungbean stover and other crop residues in soil, the $\mathrm{pH}$ remained unchanged although minor variation existed. A minor change in soil fertility occurred from initial status due to different fertilizer management practices over two years. Soil test basis fertilizer application $\left(\mathrm{T}_{4}\right)$ tended to maintain the initial fertility or increased slightly (Table 9). The treatment $\mathrm{T}_{4}$ showed an encouraging effect on organic matter, $\mathrm{N}, \mathrm{P}, \mathrm{S}, \mathrm{Zn}$ and B only. Potasium (K) slightly decreased in all plots over the initial status. The available $\mathrm{Zn}$ and $\mathrm{B}$ content of the soil slightly decreased when they were not applied $\left(T_{1}\right.$ and $\mathrm{T}_{2}$ ), but remained almost static or increase when applied (Table 9).

Table 9. Initial and post soil fertility status after two cycles of mustard-mungbean-T. aman rice cropping system due to different fertilizer management practices.

\begin{tabular}{|c|c|c|c|c|c|c|c|c|}
\hline \multirow[b]{2}{*}{ Treatment } & \multirow[b]{2}{*}{ pH } & \multirow[b]{2}{*}{ OM (\%) } & \multirow[b]{2}{*}{ Total N (\%) } & $\mathbf{K}$ & $\mathbf{P}$ & $\mathbf{S}$ & $\mathbf{Z n}$ & B \\
\hline & & & & Meq. $100 \mathrm{~g}^{-1}$ & \multicolumn{4}{|l|}{$\mu \mathrm{g} \mathrm{g}^{-1}$} \\
\hline Initial & 6.3 & 1.39 & 0.061 & 0.15 & 15.0 & 17.1 & 1.38 & 0.19 \\
\hline Control $\left(\mathrm{T}_{1}\right)$ & 6.4 & 1.39 & 0.059 & 0.13 & 15.0 & 16.3 & 1.35 & 0.17 \\
\hline F. practice $\left(\mathrm{T}_{2}\right)$ & 6.2 & 1.41 & 0.060 & 0.13 & 16.0 & 16.7 & 1.36 & 0.17 \\
\hline $\operatorname{AEZ}\left(\mathrm{T}_{3}\right)$ & 6.3 & 1.43 & 0.061 & 0.14 & 16.1 & 17.3 & 1.39 & 0.20 \\
\hline $\operatorname{STB}\left(\mathrm{T}_{4}\right)$ & 6.3 & 1.46 & 0.063 & 0.14 & 16.7 & 18.0 & 1.41 & 0.21 \\
\hline
\end{tabular}




\subsection{Economic Analysis}

The gross margin due to treatment $\mathrm{T}_{4}$ increased over farmers practice $\left(T_{2}\right)$ and AEZ $\left(T_{3}\right)$ for higher crop yield. Gross returns varied in different treatments mustardmungbean-T. aman rice cropping system which were directly related to the price that received from the product. The gross returns were highest (Tk. $232160 \mathrm{ha}^{-1} \mathrm{yr}^{-1}$ ) in the treatment $\mathrm{T}_{4}$ followed by $T_{3}$ and $T_{2}$ and the lowest was in control treatment. The highest marginal benefit cost ratio (3.46) was recorded in $T_{3}$ followed by $T_{4}$. In this study $T_{3}$ was economically viable due to the cost of production of $\mathrm{T}_{3}(\mathrm{Tk}$. $70313 \mathrm{ha}^{-1} \mathrm{yr}^{-1}$ ) was lower than $\mathrm{T}_{4}$ (Tk. $81222 \mathrm{ha}^{-1} \mathrm{yr}^{-1}$ ) (Table 10).

Table 10. Economic analysis of mustard-mungbean-T. aman rice cropping system affected by different nutrient management practices.

\begin{tabular}{|c|c|c|c|c|c|c|}
\hline \multirow[t]{2}{*}{ Treatment } & Variable cost & Gross return & $\begin{array}{l}\text { Added cost over } \\
\text { control }\end{array}$ & $\begin{array}{l}\text { Added benefit over } \\
\text { control }\end{array}$ & $\begin{array}{l}\text { Gross margin } \\
\text { over control }\end{array}$ & MBCR \\
\hline & \multicolumn{6}{|l|}{ Tk. ha $^{-1} \mathrm{yr}^{-1}$} \\
\hline Control $\left(\mathrm{T}_{1}\right)$ & 56110 & 151673 & - & - & - & \\
\hline $\operatorname{AEZ}\left(\mathrm{T}_{3}\right)$ & 70313 & 200783 & 14203 & 49110 & 34907 & 3.46 \\
\hline STB $\left(\mathrm{T}_{4}\right)$ & 81222 & 232160 & 25112 & 80487 & 55375 & 3.21 \\
\hline
\end{tabular}

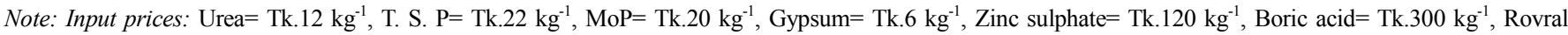
fungicide $=$ Tk.250 $100^{-\mathrm{g}}$, Bavistin fungicide $=$ Tk.200 100 ${ }^{-\mathrm{g}}$, Provex fungicide $=$ Tk.3200 kg-1, Ripcord insecticide $=$ Tk.105 $100^{-\mathrm{g}}$, Karate insecticide $=$ Tk.450 $500^{-}$ ${ }^{\mathrm{ml}}$, Plowing $=$ Tk.1400 ha ${ }^{-1}$ (one pass), Labour wage $=\mathrm{Tk} .125 \mathrm{day}^{-1}$, Mustard seed $=\mathrm{Tk} .45 \mathrm{~kg}^{-1}$, Mungbean seed $=\mathrm{Tk} .60 \mathrm{~kg}{ }^{-1}, \mathrm{~T}$. aman rice seed $=\mathrm{Tk} .35 \mathrm{~kg}{ }^{-1}$.

Output prices: Mustard grain $=$ Tk. $35 \mathrm{~kg}^{-1}$, Mungbean grain $=\mathrm{Tk} .55 \mathrm{~kg}^{-1}, \mathrm{~T}$. aman rice grain $=\mathrm{Tk} .19 \mathrm{~kg}^{-1}, \mathrm{Mustard}^{\mathrm{straw}}$ rate $=\mathrm{Tk} .1 \mathrm{~kg}^{-1}, \mathrm{Rice}$ straw $=\mathrm{Tk} .1 .25 \mathrm{~kg}{ }^{-1}$.

\section{Discussion}

The yields of all test crops were highly responded to soil test basis fertilization $\left(\mathrm{T}_{4}\right)$ followed by AEZ basis fertilization $\left(\mathrm{T}_{3}\right)$. The nutrient management practices have positive effect on the yields of mustard, mungbean and T. aman rice. Initially the soil fertility status under study was very low to low. Application of fertilizer in this soil following different management practices brought about significant yield increase over control with the highest values in soil test basis fertilization $\left(\mathrm{T}_{4}\right)$. This indicated that the treatment $\mathrm{T}_{4}$ was more balanced than that of $\mathrm{T}_{2}$ and $\mathrm{T}_{3}$. Balanced fertilization through soil test based treatment produce higher yields of crops as well as sustains soil fertilty [21]. These results are also supported by Ram and Pathak [22]; Rundala et al. [23]; Tandon and Roy [24]; Rahman et al. [18]. Mustard, mungbean and T. aman rice yields of second year were relatively higher than that of first year. Result of soil analysis was done after two crop cycles showed an increasing trend of soil fertility although some exception existed. With the inclusion of legumes in cropping system, the crop biomasses left back in the field contain nutrient including nitrogen rich residues [25]. Nawab et al. [26] and Aggarwal et al. [27] also found that incorporation of green manure into soil enhanced the fertility and yield of crop. The increased soil fertility due to incorporation of crop residues in addition to fertilization was probably the reasons for the obtained higher yield of test crops in second year over first year.

The soil test basis fertilization contributed the highest mean yield increase in test crops of $93 \%, 50 \%$ and $38 \%$ over control. This higher yield increase might be possible for more balanced fertilization than that of other treatments. Islam et al. [28] is in agreement with the findings. From the gross return and gross margin the treatment $\mathrm{T}_{4}$ is preferable and viable. Similar report was made by Malika et al. [29]. Comparision between test crops nutrient and critical values among different treatments $\mathrm{N}$ and $\mathrm{K}$ deficiency showed more pronounced. These findings are in agreement with the findings of Timsina et al. [30]; Panaullah et al. [31]. The results are also confirmed by the observation of Bell and Kovar [20] and Kalra [19].

Nutrient management practices significantly affected the uptake of N, P, K, S, Zn and B by the crops in this system at both the years. Maximum N uptake was found in STB (278 $\left.\mathrm{kg} \mathrm{ha}^{-1} \mathrm{yr}^{-1}\right)$ followed by AEZ $\left(\mathrm{T}_{3}\right)$ and minimum was in control $\left(\mathrm{T}_{1}\right)$. This finding is in line with Timsina et al. [30] who reported that $\mathrm{N}$ uptake was consistently and significantly greater due to STB fertilizer management. The treatment STB showed highest phosphorus uptake $\left(30.7 \mathrm{~kg} \mathrm{ha}^{-1} \mathrm{yr}^{-1}\right)$ followed by AEZ $\left(25.1 \mathrm{~kg} \mathrm{ha}^{-1} \mathrm{yr}^{-1}\right)$. The lowest uptake was found in control $\left(16.7 \mathrm{~kg} \mathrm{ha}^{-1} \mathrm{yr}^{-1}\right)$. Tarafder et al. [32] observed that an uptake of $\mathrm{P}$ ranged from 160 to $202 \mathrm{~kg} \mathrm{ha}^{-1}$ $\mathrm{yr}^{-1}$ in potato-boro-T. aman rice cropping pattern. Maximum potassium uptake was obtained from STB (199 $\left.\mathrm{kg} \mathrm{ha}^{-1} \mathrm{yr}^{-1}\right)$ followed by AEZ (174 $\mathrm{kg} \mathrm{ha}^{-1} \mathrm{yr}^{-1}$. Shrestha and Ladha [33] found different amount of $\mathrm{K}$ uptake by sweet pepper-fallowrice $\left(203 \mathrm{~kg} \mathrm{ha}^{-1}\right)$; sweet pepper-indigo-rice $\left(318 \mathrm{~kg} \mathrm{ha}^{-1}\right)$; sweet pepper-indigo + mungbean-rice $\left(303 \mathrm{~kg} \mathrm{ha}^{-1}\right)$; sweet pepper-corn-rice $\left(467 \mathrm{~kg} \mathrm{ha}^{-1}\right)$. Among the treatments, maximum S uptake was observed in STB $\left(35.5 \mathrm{~kg} \mathrm{ha}^{-1} \mathrm{yr}^{-1}\right)$ followed by AEZ ( $\left.30.1 \mathrm{~kg} \mathrm{ha}^{-1} \mathrm{yr}^{-1}\right)$ and the minimum was in control treatment $\left(17.6 \mathrm{~kg} \mathrm{ha}^{-1} \mathrm{yr}^{-1}\right)$. Sulphur uptake in wheatT. aus-T. aman cropping system varied from 20 to $47 \mathrm{~kg} \mathrm{ha}^{-1}$ $\mathrm{yr}^{-1}$ [34]. The uptake of other nutrients ( $\mathrm{Zn}$ and $\mathrm{B}$ ) due to different nutrients management practices followed almost the same trend of $\mathrm{N}$ uptake.

The balance of $\mathrm{N}, \mathrm{P}, \mathrm{K}, \mathrm{S}, \mathrm{Zn}$ and $\mathrm{B}$ was influenced significantly by different fertilizer treatment under mustardmungbean-T. aman cropping system. Higher $\mathrm{N}$ mining was occurred in control plot as no fertilizers were used and less mining was observed in soil test basis fertilizer treated plot. More $\mathrm{N}$ was added in soil through fertilizer as well as added 
mungbean biomass and other crop residues. Hence, the soil test basis fertilizer treatment $\left(\mathrm{T}_{4}\right)$ showed lesser mining of $\mathrm{N}$. Kumar and Goh [35] also found minimum $\mathrm{N}$ mining from balanced fertilization. On the other hand, apparent balance of $\mathrm{N}$ was negative in all the treatment and the depletion ranged from -41.0 to $-167 \mathrm{~kg} \mathrm{~N} \mathrm{ha}{ }^{-1} \mathrm{yr}^{-1}$. Some researchers supported the results: in rice-maize system in Bangladesh, the apparent nutrient balance showed highly negative for $\mathrm{N}$ (-120 to $\left.-134 \mathrm{~kg} \mathrm{ha}^{-1} \mathrm{yr}^{-1}\right)$ [36]. Phosphorus balance was positive in all $\mathrm{P}$ treated plots except control treatment $\left(\mathrm{T}_{1}\right)$ with the highest value in soil test basis fertilizer treatment $\left(\mathrm{T}_{4}\right)$ than the other treatments. This result is supported to the findings of Jahan et al. [37]. In rice-maize system in Bangladesh, the apparent $\mathrm{P}$ balance was found positive (15 to $33 \mathrm{~kg} \mathrm{ha}^{-1}$ ) [38]. The balance of $\mathrm{K}$ was negative in all the treatments where the highest mining was in control treatment. The results confirmed the declining trends in available soil $\mathrm{K}$ in many treatments and they are comparable with many other long-term studies in rice-rice and ricewheat systems of Asia [39]. Biswas et al. [40] found that the apparent average annual $\mathrm{K}$ balances were all negative and ranged from $-179 \mathrm{~kg} \mathrm{ha}^{-1} \mathrm{yr}^{-1}$ in jute-rice-rice to $-39 \mathrm{~kg} \mathrm{ha}^{-1}$ in rice-potato-sesame. Zinc and B balance was positive under all treatments except for control and farmers practice treatments. Other studies have also showed positive balance of $\mathrm{Zn}$ and $\mathrm{B}$ in maize-mungbean-rice system when it was added [21]. Similar results corroborated by Jahan et al. [41] in a monocrop cultivation of $\mathrm{T}$. aman rice where -0.08 to $0.31 \mathrm{~kg} \mathrm{Zn} \mathrm{ha}^{-1} \mathrm{yr}^{-1}$ was in control and farmers practice and positive balance (1.12 to $1.61 \mathrm{~kg} \mathrm{Zn} \mathrm{ha}^{-1} \mathrm{yr}^{-1}$ ) was in AEZ and STB treatment. The above discussion seems that $\mathrm{N}$ and $\mathrm{K}$ balance were strongly negative in soils and seasons.

\section{Conclusion}

Yields/productivity of tested system showed higher through soil test basis fertilization. The nutrient uptake by mustard, mungbean and T. aman rice were found to be higher in soil test basis treatment. Nutrients balances at the end of the cycle showed different results depending on the nutrient. The magnitude of negative balance of $\mathrm{N}$ and $\mathrm{K}$ was greater among the major nutrients. Nitrogen and $\mathrm{K}$ mining occur remarkably from the soil. So, the rates of application of these two nutrients should be increased. Considering the gross margin and soil fertility the soil test basis fertilizer management practice (STB) is economically profitable and viable for achieving sustainable crop yield. Results of the present study indicate clearly an opportunity for the readjustment of the $\mathrm{N}, \mathrm{P}, \mathrm{K}, \mathrm{S}$ and miconutrients $(\mathrm{Zn} \& \mathrm{~B})$ fertilizer doses for the different rice-based cropping systems in Bangladesh.

\section{References}

[1] FRG, (2012). Fertilizer Recommendation Guide. Published by Bangladesh Agricultural Research Council, Dhaka, Bangladesh.
[2] Timsina J, Connor DJ. (2001). Productivity and management of rice-wheat cropping system: Issues and Challenges. Field Crop Res 69:7-11.

[3] Ali AM, Alam MR, Molla MSH, Islam F. (2010). Crop productivity as affected by fertilizer management options in Boro-T. aman cropping pattern at farmers fields. Bangladesh J Agril Res 35 (2):287-296.

[4] Tirol-Padre A, Ladha JK, Regmi AP, Bhandari AL, Inubushi K. (2007). Organic amendment affect soil parameters in two long-term rice-wheat experiments. Soil Sci Soc Am J 71:44252 .

[5] Singh GB, Yadav DV. (1992). INSS in sugarcane and sugarcane based cropping system. Fert News 37 (4):15-20.

[6] Paul F, Brentrup F, Bruu Isema T, Garcia F, Norton R, Zingore S. (2014). Nutrient/fertilizer use efficiency: measurement, current situation and trends. IFA, IWMI, IPNI and IPI.

[7] Gomez KA, Gomez AA. (1984). Statistical Procedures for Agricultural Research. International Rice Research Institute, John Wiley \& Sons, NY.

[8] Nelson DW, Sommers LE. (1982). Total carbon, organic carbon and organic matter. In: Methods of Soil Analysis. Part 2. 2nd Edition. Page, A. L, Miller, R. H., Keeney, D. R. Am. Soc. of Agron. Madison, USA. Pp. 539-580.

[9] Bremner JM, Mulvaney CS. (1982). Total nitrogen, In: Methods of Soil Analysis, Part 2, 2nd Ed., Page, A. L., Miller, R. H., Keeney, D. R., Am. Soc. Agron. Madison, USA. Pp. 599-622.

[10] Jackson ML. (1973). Soil Chemical Analysis. Prentice Hall of India Private Limited, New Delhi. Pp. 498.

[11] Olsen S, Sommer LE. (1982). Phosphorus. In: Methods of Soil Analysis, Part 2. 2nd Edition. Page, A. L., Miller, R. H., Keeney, D. R., Am. Soc. Agron. Madison, USA. Pp. 403-427.

[12] Fox RL, Olsen RA, Rhoades HF. (1964). Evaluating the sulphur status of soil by plant and soil test. Soil Sci Soc Am Proc 28:243-246.

[13] Lindsay WL, Norvell WA. (1978). Development of a DTPA soil test for Zn, Fe, Mn and Cu. Soil Sci. Soc. Am. J. 42:421428 .

[14] Page AL, Miller RH, Keeney DR (eds.). (1982). Methods of Soil Analysis. Part 2. Chemical and microbiological properties. 2nd Edition. Agronomy series 9 ASA, SSSA. Madison Wis. USA.

[15] Piper CS. (1966). Soil and Plant Analysis. Adelaide University Press, Australia.

[16] Hanks RJ, Ashcroft GL. (1980). Applied Soil Physics; Soil Water and Temperature Applications. Springer-verlag Berlin, Heidelberg, Newyork. Pp. 1-159.

[17] Quayyum MA, Timsina J, Jahan MAHS, Ara R, Connor DJ. (2002). Grain Yield and System Productivity for Rice-WheatMungbean and Rice-Wheat-Maize Sequences in Northern Bangladesh. Thai J Agric Sci 35 (1):51-62.

[18] Rahman MH, Islam MR, Jahiruddin M, Haque MQ. (2011). Economics of fertilizer use in the Maize-Mungbean/DhainchaT. aman rice cropping pattern. J. Bangladesh Agril. Univ. 9 (1):37-42. 
[19] Kalra PK (editor). (1998). Handbook of reference Methods for Plant Analysis. Published by CRC Press, Taylor \& Francis Group. New Yark.

[20] Bell PF, Kovar JL. (2000). Reference sufficiency ranges for plant analysis in the southern region of the United States, Editor C. Ray Campbell. Southern Cooperative Series Bulletin p 394.

[21] Hossain MA, Jahiruddin M, Islam MR, Mian MH. (2008). The requirement of zinc for improvement of crop yield and mineral nutrition in the maize-mungbean-rice system. Plant Soil 306:13-22.

[22] Ram LP, Pathak J. (2016). Effect of integrated nutrient management on yield and Economics of mustard. Interntionl Journal of Science and Nature. Vol.7 (2) 2016:255-261.

[23] Rundala SR, Kumawat BL, Choudhary GL, Prajapat K, Sit Kumawat. (2013). Performance of Indian mustard (Brassica juncea) under integrated nutrient management. Crop Res 46 (1, 2 \& 3): 115-118. India.

[24] andon Roy. (2004). Nutrient management guidlines for some major crops. Chapter-8. Published by FAO.

[25] Ussiri DA, Lal R, Jacinthe PA. (2006). Postreclamation land use effects on properties and carbon sequestration in minesoils of southeastern Ohio. Soil Sci 171:261-271.

[26] Nawab K, Amanullah, Shah P, Rab A, Arif M, Azim Khan M, Mateen A, Munsif F. (2011). Impact of integrated nutrient management on growth and grain yield of wheat under irrigated cropping system. Pakistan J Bot 43 (4):1943-1947.

[27] Aggarwal P, Parashar DK, Kumar V, Gupta RP. (1997). Effect of kharif green manuring and rabi tillage on physical properties of clay loam under rice-wheat rotation. J Indian Soc Soil Sci 45 (3):434-438.

[28] Islam MR, Karim MR, Riasat TM, Jahiruddin M. (1996). Growth and yield of BR11 rice under different levels of sulphur, zinc and boron fertility at two locations of Bangladesh. Thai J Agric Sci 29:37-42.

[29] Malika M, Islam MR, Karim MR, Huda A, Jahiruddin M. (2015). Organic and inorganic fertilizers influence the nutrient use efficiency and yield of a rice variety BINA dhan7. Acad. Res. J of Agril Sci Res 3 (7):192-200.

[30] Timsina J, Panaullah GM, Saleque M, Ishaque M, Pathan ABMBU, Quayyum MA, Connor DJ, Saha PK, Humphreys EC, Meisner CA. (2006). Nutrient Uptake and Apparent Balances for Rice-Wheat Sequences. I. Nitrogen. Journal of Plant Nutrition 29:137-155.

[31] Panaullah GM, Timsina J, Saleque MA, Ishaque M, Pathan ABMBU, Connor DJ, Saha PK, Quayyum MA, Humphreys E,
Meisner CA. (2006). Nutrient uptake and apparent balances for rice-wheat sequences. III. Potassium. Journal of Plant Nutrition 29:173-187.

[32] Tarafder MA, Haque MQ, Rahman MM, Khan MR. (2008). Direct and residual effect of sulphur and zinc on potato-boroT. aman rice cropping pattern. Progress Agric 19 (1):33-38.

[33] Shrestha RK, Ladha JK. (2001). Nutrient balances in a ricevegetable system: a case study of an intensive cropping system in Ilocos Norte, the Philippines. International Workshop on Nutrient Balances for Sustainable Agricultural Production and Natural Resource Management in Southeast Asia. Bangkok, Thailand.

[34] Haque MQ, Rahman MH, Begum R, Islam MF. (2002). Integrated use of inorganic and organic fertilizers in Wheat-T. aus-T. aman rice cropping pattern for sustained crop production. 17th WCSS, 14-21 August 2002. Symposium no. 13, Paper no. 354 Thailand.

[35] Kumar K, Goh KM. (2000). Biological nitrogen fixation, accumulation of soil nitrogen and nitrogen balance for white clover (Trifolium repens L.) and field pea (Pisum sativum L.) grown for seed. Field crops Res 68:49-59.

[36] Timsina J, Mangi LJ, Majumdar K. (2010). Rice-maize systems of South Asia: current status, future prospects and research priorities for nutrient management. Plant Soil 335:65-82.

[37] Jahan MAHS, Sarkar MAR, Barma NCD, Mondal MNA, Ferdousi MNS. (2015a). Seed yield, nutrient balance and economics of mungbean cultivation as influenced by different nutrients management under AEZ-28. Bangladesh J Agril Res 40 (1):77-93.

[38] Ali MR, Rahman MS, Mannan MA, Hossain MM, Kadir M. (2009). Balanced fertilization with inorganic fertilizers in Mustard-Boro-T. aman cropping pattern. Bangladesh J Prog Sci Tech 1 (1):33-37.

[39] Ladha JK, Dawe D, Pathak H, Padre AT, Yadav RL, Singh B, Singh Y, Singh P, Kundu AL, Sakal R, Ram N, Regmi AP, Gami SK, Bhandari AL, Amin R, Yadav CR, Bhattarai EM, Das S, Aggarwal HP, Gupta RK, Hobbs PR. (2003). How extensive are yield declines in long-term rice-wheat experiments in Asia? Field Crops Res 81:159-180.

[40] Biswas B, Ghosh DC, Dasgupta MK, Trivedi N, Timsina J, Dobermann A. (2006). Integrated assessment of cropping systems in the Eastern Indo-Gangetic plain. Field Crops Res 99:35-47.

[41] Jahan, MAHS, Sarkar MAR, Barma NCD, Mondal MNA, Ferdousi MNS. (2015b). Grain yield, nutrient balance and economics of $\mathrm{T}$. aman rice cultivation as influenced by nutrients management. Bangladesh J Agril Res 40 (1):17-34. 